\title{
Herbal informatics: A unique model to identify the anti-cancerous agents for targeting lung cancer
}

Rashmi Wardhan ${ }^{1^{*}}$, Ankit Tanwar ${ }^{2 *}$, Pallavi Dutta ${ }^{1}$, Ishita Jha ${ }^{1}$, Ruby Sharma ${ }^{3}$, Ayesha Ali Zaidi ${ }^{4}$,

$$
\text { Raman Chawla }{ }^{5} \text {, Rajesh } \text { Arora }^{6} \text {, Haider Ali Khan }{ }^{4}
$$

${ }^{1}$ Department of Biochemistry, Shivaji College, University of Delhi (DU), New Delhi-110027, India

${ }^{2}$ Department of Cell Biology, Albert Einstein College of Medicine, New York, NY, 10461, USA

${ }^{3}$ Department of Microbiology and Immunology, Albert Einstein College of Medicine, New York, NY, 10461, USA

${ }^{4}$ Department of Medical Elementology \& Toxicology, Jamia Hamdard, Delhi - 110062, India

${ }^{5}$ Division of CBRN Defence, Institute of Nuclear Medicine and Allied Sciences, Delhi - 110054, India

${ }^{6}$ Department of Biochemical Sciences (DBCS), Defence Institute of Physiology and Allied Sciences (DIPAS), Delhi, India

*Corresponding authors:

1. Rashmi Wardhan, Associate Professor, Department of Biochemistry, Shivaji College, University of Delhi (DU), New Delhi-110027,India; E-mail: rashmiwardhan56@gmail.com,rwardhan@shivaji.du.ac.in

2. Ankit Tanwar, Scientist, Department of Cell Biology, Albert Einstein College of Medicine, New York, NY, 10461, USA;E-mail: tanwar.ankit9@gmail.com

\section{Highlights.}

- Lung cancer is a life threating disease, which causes $60 \%$ of deaths in patients within a year.

- Current management is not effective to ameliorate the progression of disease and has several side effects

- This study utilized a novel herbal informatic to provide an alternative curative drug using binary index and rationale-based selection.

- Study scrutinized 07 natural products, that has drug ability to target lung cancer in mammalian systems followed by its cross validation at molecular docking level.

- This unique bioprospection study could be beneficial for drug discovery process in future. 


\begin{abstract}
The incidence of lung cancer has increased in recent years and causes major mortalities across the globe . Besides, the availability of the several chemotherapeutics modalities in the management, there is still a challenge to find out the efficient remedy with lesser or no toxic effects. Hence, there is a necessity to employ a complementary research to establish the effective management for the lung cancer. In this study, we have implemented a novel herbal informatics model to find out the alternative remedy in treatment of lung cancer. This model utilizes five major steps of bioprospection process based on the classical surge followed by the binary index and rationale-based selection of herbal products targeting the cancer-causing factors which is explained in detail in the methodology section of this model. This study revealed 07 herbals such as Withania somnifera (Ws), Berberis vulgaris(Bv), Glycyrrhiza glabra(Gg), Andrographis paniculate(Ap), Azadirachta indica $(A i)$, Cinnamomum verum $(C v)$, Piper longum $(P l)$ based on the fuzzy set optimization scoring $(0.6-1)$ that could be further studied in vitro and in vivo level for utilization in the management of lung cancer.
\end{abstract}

Keywords: Herbal Informatics; Ayurveda; Lung Cancer; Ethnopharmacology; Natural Compounds; Alternative Medicine 


\section{Introduction}

Lung cancer is a major health issue, that is caused due to a variety of genetic and environmental factors and is reported to cause the major mortalities all around the world [1,2]. Researchers, while predicting the mortalities related to lung cancer globally, estimated around 1.7 million deaths in 2018 [3]. Two major categories of lung cancer, namely, Small Cell Lung Cancer (SCLC) and Non Small Cell Lung Cancer (NSCLC) account for 15\% and $85 \%$ of all Lung cancer cases respectively. Histologically and clinically, NSCLC is categorized into adenocarcinomas, squamous cell carcinomas and large cell carcinomas [4].

The various pathways like the tyrosine kinase family, epidermal growth factor receptors (EGFR) are over expressed in cancers. Various other anomalies have also been reported like, KRAS gene mutation, PI3K gene mutations, fusions in ALK genes etc.[5] Vascular endothelial growth factor (VEGF), that underlies angiogenesis is also reportedly increased in NSCLC and other cancers [6]. The gene encoding for Anaplastic Lymphoma Kinase(ALK) is reported to undergo rearrangement in some cases of non-small cell lung cancer (NSCLC). [7]. Anaplastic lymphoma kinase (ALK) and echinoderm microtubule-associated protein-like 4 (EML4) are over expressed in 3-13\% of lung cancers.[8, 9]. In hypoxic state Histone Deacetylases (HDAC) causes angiogenesis.[10]The phosphoinositide 3-kinase (PI3K) /downstream serine/threonine kinase (Akt)are found to be involved in anti-apoptotic signals in non-small cell lung cancers (NSCLC)[11, 12]. Tubulins, the multifunctional proteins participate in chromosome separation during cell division, intracellular transport, cell shape modulation. The $\gamma$-tubulin in non-small cell lung cancer (NSCLC) is over expressed and also impacts patient survival at advanced stages of NSCLC [13] Fibroblast growth factor receptor (FGFR) is involved in regulation of cell proliferation, differentiation, shape and movement and causes angiogenesis[14, 15]. FGF 9 factor, ligand of FGFR3, is over expressed in lung breast, prostate cancers .[16] Both autocrine and paracrine pathways simultaneously activate epidermal growth factor receptors (EGFR) to secrete epidermal growth factors molecules, which activate targeted signal transduction pathways and transfer cellular information from EGFR to the inner side of lung cells.[17] The epidermal growth factors promote lung metastasis through EGFR-receptor tyrosine kinases (RTK) by initiating and triggering signaling cascade in NSCLC and SCLC both.[18]

Several factors/pathways can be targeted by active constituents present in herbal compounds to regulate the signaling pathways. As today apart from surgery, radiation, systematic therapy like chemotherapy, targeted therapy, antibody treatment and angiogenesis inhibitors medication are also given to lung cancer patients . Various chemotherapeutics agents are also available for general and targeted therapy for lung cancer that is approved by FDA (The US Food and Drug Administration) and/or EMA (European Medicines Agency) such as carboplatin, cisplatin, paclitaxel, Gefitinib (anti-EGFR), Crizotinib (anti-MET, anti ALK and anti ROS1), Lorlatinib (anti-ALK) etc. [19]. The proliferating cancer cells are susceptible to chemotherapy but also has various side effects like nausea, diarrhea, weakness, lethargy, hair loss as routine. Some-times chemical drugs may have serious side effects like myelotoxicity [20], cardiotoxicity[21], renal toxicity [22] Chemotherapy medicines may affect blood-forming cells in bone marrow. The long term usage of anti-cancer drugs is seen in increasing mutation in EGFR gene and amplifying mesenchymal-epithelial transition ( $c$-MET) protooncogene and it also leads to the development of non-responsiveness to these therapies.[23] 
Herbal compounds are most popular among all medications known till date, and has several medicinal properties like healing, immune boosting, anti-bacterial, rejuvenating and purifier activity in them. They are being used as primary medicines to treat number of disorders with less or no side effects.[24] In Ayurveda , thousands of years ago, the herbals with their therapeutic uses were described to treat various human disorders as various forms of concoction. The NIH National cancer institute (NCI) reported 3000 herbals with confirmed anticancer properties [25]. Herbal derived anticancer medicines have been categorized into four classes according to their mechanism of action such as Tubulin inhibitors (vinca alkaloids, taxanes), HDAC inhibitors (various isoflavonoids), Topoisomerase I and II inhibitors ( Camptothecins and podophyllotoxins) and DNA disrupters (epigallocatechin-3-gallate)[26]. Various herbals have been proven to exert anti-cancer mechanisms via regulating various pathways. Neem (Azadirachta indica), a well-known Ayurvedic herb, has been shown to exert various activities like antibacterial, antifungal, anti-inflammatory etc. It has also displayed anticarcinogenic activities via phytochemicals like quercetin, nimbolide etc. [27, 28] In this research article, various other herbal compounds have been described in Table 2, with similar properties. These herbals have a number of active ingredients, but these molecules and their target hits have to be identified. The various side effects of chemotherapy in patients has persuaded scientist to study herbals derivatives as alternate medicines to alleviate disease like cancer. The complex nature of lung cancer poses challenges to present medicines available and persuades researchers to find new medicines. The present insufficient systematic research for herbals and their specific molecule is a limiting factor for lung cancer treatment. The traditional process is tedious and time consuming and thereby irrational. In this study in-silico herbal informatic model, we are bio-prospecting the several medicinal herbs to identify their potential for targeting specific factors/pathways that are responsible for lung cancer. Web based data search engine, matrix linked data mining and Fuzzy score based validation and identification for probable therapeutic efficiency of the screened plants have been done. The large analogous research on target factors of lung cancer and herbs are available on web, which were filtered on number of direct hits for further 'in silico' research. This novel tool thus widens the opportunity for further 'in vivo' or 'in vitro' research and systematic development of lung cancer targeting plant-based drugs based on the plants shortlisted. [29].

\section{Methodology}

\subsection{Traditional literature surge model}

The WHO data for lung cancer estimated 2.09 million cases and 1.76 million mortalities in 2018 . American Cancer Society estimated 135,720 deaths from lung cancer (72,500 in men and 63,220 in women) in USA in 2020 [30]. The present limited treatments for lung cancer, chemotherapy limitations and its side effects with poor recovery rates (According to latest lung cancer statistics, five year survival rate is 19\%) are the basis for selecting lung cancer for herbal targeting. A classical literature torrent search was done to identify 10 specific pathological factors like Tubulin ,Histone Deacetylases (HDAC), Epidermal Growth Factor Receptor (EGFR), Anapestic Lymphoma Kinase (ALK), Fibroblast Growth Factor Receptor (FGFR) and Phosphoinositide 3-Kinase (PI3K), Akt (serine/threonine-specific protein Kinase B), Signal Transducer 
and activator of transcription 3(STAT3) and KRAS (Kirsten rat sarcoma viral oncogene homolog) were selected as presented in Table 1.

Similarly, database of herbals was prepared based on the selection criterions included Ethno-pharmacological properties, Traditional uses, Availability at ease, therapeutic potential associated with indirect indications and literature support as exemplified in Table 2 [31].

\begin{tabular}{|c|c|c|}
\hline $\begin{array}{l}\text { S. } \\
\text { No }\end{array}$ & $\begin{array}{c}\text { Bioactivity } \\
\text { parameters (BAP) }\end{array}$ & Rationale for selection (Based on classical surge) \\
\hline & EGFR & $\begin{array}{l}\text { i. Growth factor receptor (transmembrane) that is a part of HER/erbB } \\
\text { tyrosine kinase family, and it controls proliferation and death of cell } \\
\text { (apoptosis). This receptor is overexpressed in NSCLC. } \\
\text { ii. According to research, Cucurbitacin B, a phytochemical, caused } \\
\text { degradation of EGFR via lysosomes in NSCLC cells. } \\
\text { iii. Plant product lupeol can cause reduction in EGFR protein by binding } \\
\text { to it and phosphorylating it. }\end{array}$ \\
\hline & ALK & $\begin{array}{l}\text { i. Function as a receptor tyrosine kinase and it undergoes mutations } \\
\text { (translocation/fusion) in various cancers increases proliferation, } \\
\text { metastasis and prevents cell death. It plays an important role in } \\
\text { development of lung cancer, mainly NSCLC. } \\
\text { ii. Phytochemicals from Vitex negundo namely: 6'-para-hydroxybenzoyl } \\
\text { mussaenosidic acid, protocatechuic acid, viridiflorol and betulinic } \\
\text { acid could effectively inactivate ALK protein in lymphoma cells. }\end{array}$ \\
\hline & $\begin{array}{l}\text { PI3K } \\
\text { (Phosphoinositide 3- } \\
\text { kinase) }\end{array}$ & $\begin{array}{l}\text { i. It is a kinase enzyme that acts in converting PI }(3,4) \text {-bisphosphate to } \\
\text { PI }(3,4,5) \text {-trisphosphate leading to subsequent localization of Protein } \\
\text { Kinase B (Akt) to the cell membrane. In various cancers, this kinase } \\
\text { enzyme is upregulated (over-expressed) and is crucial in apoptosis, } \\
\text { metastasis, angiogenesis etc. } \\
\text { ii. Involved in lung cancer and it frequently was found to co-exist with } \\
\text { deletion (loss) of PTEN genes, } \\
\text { iii. Phytochemicals (e.g. Andrographolide from Andrographis } \\
\text { 5tilbene5e) that cause inhibition of PI3K or the downregulation of its } \\
\text { phosphorylated forms and these can be beneficial in cancer therapy. }\end{array}$ \\
\hline & Tubulin & $\begin{array}{l}\text { i. Important structural components of microtubule and these exist in the } \\
\text { form of two subunits namely alpha and beta. These are involved } \\
\text { normally in transport within the cell, signaling of the cell and various } \\
\text { stress responses. } \\
\text { ii. Responsible for development of aggressiveness and resistance to } \\
\text { therapy in various cancers and involved in the progression of } \\
\text { adenocarcinoma of lungs and in conferring chemo-resistance to the } \\
\text { tumors. } \\
\text { iii. Various compounds from plant Vinca (Vincristine, Vinblastine) can } \\
\text { block the assembly of tubulins. }\end{array}$ \\
\hline
\end{tabular}


HDAC

(Histone Deacetylase) i. Protein that is involved in the deacetylation reaction in the histones of chromatin but in case of many cancers the activity of this protein becomes over expressed and the resulting reduced acetylation of histones causes faulty expression of various genes.

ii. According to research, inhibitors of HDAC (namely SAHA) can reduce the growth of NSCLC tumors and it's also linked HDAC to SCLC by showing that an inhibitor of this protein (namely TSA) can reduce the proliferative properties of SCLC cells.

iii. Phytochemicals like curcumin can cause the reduction in the expression of various types of HDAC in various cancer cell lines.

Fibroblast growth

factor receptor

(FGFR)

i. It is a type of receptor tyrosine kinase present in cell membrane that normally in involved in growth processes, survival, and differentiation of cells.

ii. In many cancer cell types; research has shown this receptor to be over expressed and significant proportion of patients with NSCLC had elevated levels of FGFR and its also demonstrated that the inhibition of this protein led to reduction in growth and proliferation of the tumor cells.

iii. Various phytochemicals show anti-FGFR activities e.g. Boswellia papyriferaii derived 6 tilbene glycosides directly block FGFR by binding to it.

Serine/threoninespecific protein Kinase $\mathrm{B}(\mathrm{Akt})$ i. It is also called Protein Kinase B and is involved in survival of the cells.

ii. It is reported to be activated by various growth factors and is found to be over-expressed in many cancer types and significant proportion of NSCLC cells this protein is overexpressed, and it causes the cells to acquire immunity to various therapies (Chemo and radiotherapy). This protein is reported to cause delaying of apoptosis in the NSCLC cells.

iii. Study reported that a naturally occurring phytochemical, Piperine, causes blocking of Akt protein and thus it has anti-angiogenesis properties against various cancer cells.

\section{STAT3}

(Signal Transducer and Activator of Transcription 3) i. It is an important component of the signaling pathway in cytoplasm and it also acts as a factor of transcription.

ii. Researchers have reported that in various cancers, this factor is involved in conferring malignancy and chemoresistance to cells as well as enhancing their proliferation. STAT3 has also been found to be involved in lung cancer, especially NSCLC where it is overexpressed (in both phosphorylated and normal forms).

iii. Study reported that phytochemicals could inhibit the phosphorylation of STAT 3 by TNF-alpha and blocked its translocation to the nucleus and could effectively block phosphorylated STAT3.
KRAS i. It is a member of RAS family that encodes two GTPase proteins namely KRAS4A and KRAS4B as it undergoes alternative splicing. It has been reported that in NSCLC, KRAS gene is mutated and it leads to development of tumor.

ii. Researchers reported that mutations in RAS is cause over activation of RAF-ERK and PI3k-Akt pathways.

iii. Phytochemical Krukovine, obtained from Abuta grandifolia caused reduction in growth of Lung cancer cells with mutated KRAS as its inactivated RAF-ERK and Akt pathways. 
Bcl-2

(B-cell Lymphoma 2) i. Family of proteins that plays important role in apoptosis and it causes prevention of programmed death of the cells.

ii. The expression of BCL-2 and thus the subsequent delay in apoptosis has been observed in both SCLC and NSCLC.

iii. Research showed that phytochemical from Mentha arvensis, could cause down regulation of BCL-2 and this can also be used for its anticancer property.

\section{Table 1- Bioactivity parameters and their reason for selection}

\subsection{Relevance factors-based analysis of binary matrix}

50 herbals were identified initially as anti-cancer agents. The combination keyword search combining Anticancer agents and lung cancer causing factor inhibition, followed by linking it with observations based analysis of the first 20 hits, relevance factor/Net-Weightage of each cancer causing factor was evaluated using following formula (Equation 1)

$$
\text { Percentage relevance }=\frac{\text { Relevant Hits } \times 100}{20}
$$

The primary database set of Herbal Plants combined with the presence/absence of a given parameter was prepared using the web search engine, PubMed ( $\mathrm{N}=$ first 20 hits) with a median value as cut off filter value. [32]

\subsection{Relevance factor linked Binary weightage matrix-based analysis}

The relevance of each cancer-causing factor was used for calculation of its respective Weightage score and subsequent analysis by consideration of every plant with respect to all the cancer causing factors taken together was performed. These parameters for weightage calculation increased the 'uncertainty factor' required for statistical analysis to be viable and bring about reduction in "Investigator's prejudice". Herbals with binary score $\geq 10$, from previous step were taken into consideration for further study.

\subsection{Fuzzy set membership analysis for decision matrix \& optimization}

The mathematical relationship as mentioned below (Equation. 2) was used to assign the relative relevance via Fuzzy score analysis within identified group of plants.

$$
\mu S=\text { Score }- \text { MinS / MaxS }- \text { MinS }
$$

Where, $\mu \mathrm{S}$ represents the desirability values of selected herbal plants of the fuzzy set S. Min (S) and Max (S) correspond to the minimum and maximum fuzzy scores, respectively, in the fuzzy set under consideration (S). The estimated desirability values $(\mu \mathrm{S})$ were converted into a leveled score via a scaled magnitude to optimize the values and thus leading to identification of potential anti-lung cancer herbal agents. [33] 


\section{Results}

\subsection{Classical literature surge:}

The classical literature search brought forward 10 cancer causing factors as shown in Table $\mathbf{1}$ and the data base of 50 plants eventually led to shortlisting of $\mathbf{1 9}$ herbal compounds whose Binary score value range from 4 to 14 with mean value 8.85 ) and weightage score ranging from 39.789 to 222.156 (mean value $=133.167$ ) which showed relevance towards the 10 pathological factors are described in Table 2.

\begin{tabular}{|c|c|c|c|c|c|c|}
\hline S.No. & Herbals & $\begin{array}{c}\text { Herbal } \\
\text { code }\end{array}$ & Region & $\begin{array}{c}\text { Active } \\
\text { phytoconstituents }\end{array}$ & $\begin{array}{l}\text { Ethno- } \\
\text { pharmacological } \\
\text { importance }\end{array}$ & Traditional use \\
\hline 1. & $\begin{array}{l}\text { Andrographis paniculata } \\
\text { Hindi: Kirayat } \\
\text { English: King of Bitters }\end{array}$ & Ap & $\begin{array}{c}\text { India } \\
\text { Malaysia } \\
\text { South east } \\
\text { Asia }\end{array}$ & $\begin{array}{c}\text { Andrographolide } \\
\text { (Anticancer), } \\
\text { Neoandrographolide, } \\
\text { Dehydroandro } \\
\text { grapholide }\end{array}$ & $\begin{array}{c}\text { Antitumor } \\
\text { Anti-inflammatory, } \\
\text { Immune booster, } \\
\text { Analgesic, Antiviral } \\
\text { Cardioprotective, } \\
\text { Hepatoprotective }\end{array}$ & $\begin{array}{l}\text { Tonsillitis, } \\
\text { Tuberculosis, } \\
\text { Pneumonia, } \\
\text { Hepatitis A, } \\
\text { Leptospirosis }\end{array}$ \\
\hline 2. & $\begin{array}{l}\text { Azadirachta indica } \\
\text { Hindi: Neem } \\
\text { English: Azadirachta } \\
\text { Indica }\end{array}$ & Azi & $\begin{array}{l}\text { India } \\
\text { Asia }\end{array}$ & & $\begin{array}{c}\text { Anticancer } \\
\text { Antitumor, } \\
\text { Antioxidant, } \\
\text { Immunostimulatory, } \\
\text { Hepatoprotective }\end{array}$ & $\begin{array}{l}\text { skin disorders, } \\
\text { pains, fever, } \\
\text { antibacterial } \\
\text { Antiviral } \\
\text { Insecticide. } \\
\text { Used in dengue }\end{array}$ \\
\hline 3. & $\begin{array}{l}\text { Berberis vulgaris } \\
\text { Hindi: Daruharidra, } \\
\text { Daruhaldi } \\
\text { English: Barberry }\end{array}$ & Bvi & $\begin{array}{l}\text { India, } \\
\text { Iran, Italy, } \\
\text { Bulgaria, } \\
\text { China, } \\
\text { Turkey } \\
\text { France, }\end{array}$ & $\begin{array}{l}\text { Berberine, } \\
\text { Berbamine, } \\
\text { Acanthine } \\
\text { Aesculetine, } \\
\text { Berberrubine, } \\
\text { Chrysanthemice, } \\
\text { Columbamine, }\end{array}$ & $\begin{array}{c}\text { Anti-cancer, } \\
\text { Antitumor, } \\
\text { Anti-inflammatory, } \\
\text { Antioxidants, } \\
\text { Cardioprotective, } \\
\text { Neuroprotective, } \\
\text { Anti-arthritis }\end{array}$ & $\begin{array}{c}\text { kidney diseases, } \\
\text { hypertension, } \\
\text { liver diseases, } \\
\text { Respiratory } \\
\text { diseases }\end{array}$ \\
\hline 4. & $\begin{array}{l}\text { Caesalpinia sappan } \\
\text { Hindi: Patranga } \\
\text { English: Brazil wood }\end{array}$ & Cs & $\begin{array}{l}\text { India, China, } \\
\text { Japan, Brazil, } \\
\text { South East } \\
\text { Asia, Europe }\end{array}$ & $\begin{array}{c}\text { Brazillin } \\
\text { Caesalpin J ,P } \\
\text { Protosappanins, } \\
\text { Ombuin, } \\
\text { Rhamnetin, } \\
\text { Chromanones, } \\
\text { Chalcones }\end{array}$ & $\begin{array}{c}\text { Anticancer, } \\
\text { Antitumor, } \\
\text { Immune booster } \\
\text { Anti-inflammatory, } \\
\text { Anticoagulant, } \\
\text { Hepatoprotective }\end{array}$ & $\begin{array}{l}\text { Used for } \\
\text { wounds healing, } \\
\text { ulcers, leprosy, } \\
\text { epilepsy, } \\
\text { diabetes, } \\
\text { rheumatism. }\end{array}$ \\
\hline 5. & $\begin{array}{l}\text { Capparis } \\
\text { spinosa } \\
\text { Hindi /Sanskrit: } \\
\text { Kantaka } \\
\text { English: Caper bush }\end{array}$ & Csp & $\begin{array}{c}\text { India } \\
\text { Mediterranea } \\
\text { n region, } \\
\text { Africa, } \\
\text { West and } \\
\text { Central Asia }\end{array}$ & $\begin{array}{l}\text { Quercetin } \\
\text { glucocapparin, } \\
\text { glucoiberin, } \\
\text { glucopangulin, } \\
\text { astragalin, } \\
\text { Cappariside, } \\
\text { corchoionoside }\end{array}$ & $\begin{array}{c}\text { Anti-cancer, } \\
\text { Antitumor, } \\
\text { Anti-inflammatory, } \\
\text { Antioxidant, } \\
\text { Hepatoprotective } \\
\text { Anti-HIV, } \\
\text { Antimutagenic }\end{array}$ & $\begin{array}{l}\text { Used in } \\
\text { diarrhea, gout, } \\
\text { rheumatism, } \\
\text { spleen diseases, } \\
\text { eye diseases. }\end{array}$ \\
\hline
\end{tabular}




\begin{tabular}{|c|c|c|c|c|c|c|}
\hline 6. & $\begin{array}{l}\text { Cassia tora } \\
\text { Hindi: Charota } \\
\text { English: Sickle Senna }\end{array}$ & $\mathrm{Ct}$ & $\begin{array}{l}\text { India, } \\
\text { Sri Lanka, } \\
\text { West China }\end{array}$ & $\begin{array}{c}\text { modin, } \\
\text { Chrsyphanol, } \\
\text { anthraquinone, } \\
\text { Rubrofusarin, } \\
\text { Friendlin, } \\
\text { Quercetin, } \\
\text { Aurantio-obtusin } \\
\text { Obtusifolin, }\end{array}$ & $\begin{array}{c}\text { Anticancer, } \\
\text { Antitumor } \\
\text { Antioxidant, } \\
\text { Anti-inflammatory, } \\
\text { Antihepatotoxic, } \\
\text { Antimutagenic, }\end{array}$ & $\begin{array}{l}\text { Used in liver } \\
\text { disorders, } \\
\text { blurriness of } \\
\text { eyes, bronchitis, } \\
\text { cough, heart } \\
\text { disorders, }\end{array}$ \\
\hline 7. & $\begin{array}{l}\text { Cinnamomum verum } \\
\text { Hindi: daalacheenee } \\
\text { English: Cassia }\end{array}$ & $\mathrm{Cv}$ & $\begin{array}{l}\text { Sri Lanka and } \\
\text { Southern } \\
\text { parts of India }\end{array}$ & $\begin{array}{c}2 \\
\text { Methoxycinnamaldehy } \\
\text { de, } \\
\text { Cuminaldehyde, } \\
\text { Gallic acid, }\end{array}$ & $\begin{array}{l}\text { Anti-lung cancer } \\
\text { Antioxidant, } \\
\text { Antimicrobial, } \\
\text { Antifungal, } \\
\text { Hypotensive, }\end{array}$ & $\begin{array}{l}\text { Antimicrobial } \\
\text { used in } \\
\text { Respiratory, } \\
\text { digestive, } \\
\text { cardiovascular, } \\
\text { Alzheimer's } \\
\text { disease, }\end{array}$ \\
\hline 8. & $\begin{array}{l}\text { Commiphora myrrha } \\
\text { Hindi: Bolah } \\
\text { English: Myrrha }\end{array}$ & $\mathrm{Cm}$ & $\begin{array}{l}\text { India } \\
\text { Pakistan, } \\
\text { Arabia, } \\
\text { Southern } \\
\text { Africa }\end{array}$ & $\begin{array}{l}\text { Guggulsterone } \\
\text { Eugenol, } \\
\text { Myrrholic acid, } \\
\text { lindestrene, } \\
\text { myrrhone, } \\
\text { anthracene } \\
\text { Germacrene B }\end{array}$ & $\begin{array}{l}\text { Anti-cancer } \\
\text { Analgesic, } \\
\text { Antibacterial, } \\
\text { Antioxidant }\end{array}$ & $\begin{array}{l}\text { Used in stomach } \\
\text { illnesses, } \\
\text { bronchitis, } \\
\text { asthma, flu, }\end{array}$ \\
\hline 9. & $\begin{array}{l}\text { Foeniculum vulgare } \\
\text { Hindi: Saunf } \\
\text { English: Fennel }\end{array}$ & $\mathrm{Fv}$ & $\begin{array}{l}\text { India (mainly } \\
\text { Northern } \\
\text { India) } \\
\text { Europe }\end{array}$ & $\begin{array}{c}\text { Anethole Fenchone, } \\
\text { Anisaldehye, } \\
\text { Quercetin, } \\
\text { Orutinoside, } \\
\text { Rosmarinic acid }\end{array}$ & $\begin{array}{c}\text { Anticancer } \\
\text { Antioxidant } \\
\text { Antibacterial, } \\
\text { Anti-inflammatory, } \\
\text { Anti-atherogenic, } \\
\text { Hepatoprotective, } \\
\text { Memory-enhancer. }\end{array}$ & $\begin{array}{l}\text { Abdominal } \\
\text { problems, } \\
\text { sedative, anti- } \\
\text { diabetes, } \\
\text { bronchitis, } \\
\text { kidney stones, } \\
\text { eye diseases. }\end{array}$ \\
\hline 10. & $\begin{array}{l}\text { Glycyrrhiza glabra } \\
\text { Hindi: Madhuka } \\
\text { English: Liquorice }\end{array}$ & $\mathrm{Gg}$ & $\begin{array}{c}\text { India } \\
\text { Temperate } \\
\text { countries of } \\
\text { the World }\end{array}$ & $\begin{array}{l}\text { Formononetin } \\
\text { Glycyrrhizin, } \\
\text { Liquirtin, } \\
\text { Liquirtigenin, } \\
\text { licoriphenone, }\end{array}$ & $\begin{array}{c}\text { Anti-lung cancer } \\
\text { Anti-tumor, } \\
\text { Antioxidant, } \\
\text { Hepatoprotective, } \\
\text { Anti-inflammatory, } \\
\text { Immunostimulatory, } \\
\text { Cardioprotective, }\end{array}$ & $\begin{array}{l}\text { Used for } \\
\text { cardiac diseases, } \\
\text { haemorhage, } \\
\text { eye diseases, } \\
\text { jaundice. } \\
\text { Osteoarthritis, }\end{array}$ \\
\hline 11. & $\begin{array}{l}\text { Hygrophila spinosa } T \text { ander } \\
\text { Hindi: Talim Khana } \\
\text { English: Hygrophila, }\end{array}$ & Hsn & $\begin{array}{c}\text { India } \\
\text { (Himalayas) } \\
\text { Sri Lanka, } \\
\text { Nepal, } \\
\text { Myanmar, } \\
\text { Malay }\end{array}$ & $\begin{array}{c}\text { Tannins, } \\
\text { Lupeol, } \\
\text { Betulin, } \\
\text { Terpenoids, } \\
\text { Alkaloids, } \\
\text { Phenolic compounds, }\end{array}$ & $\begin{array}{c}\text { Anticancer, } \\
\text { antitumor } \\
\text { Anti-inflammatory, } \\
\text { Hematopoietic, } \\
\text { Antioxidant } \\
\text { Hepatoprotective, } \\
\text { Analgesic, }\end{array}$ & $\begin{array}{c}\text { Blood disorders, } \\
\text { Biliousness, } \\
\text { Hepatic } \\
\text { obstruction, } \\
\text { inflammations, } \\
\text { joint pains, }\end{array}$ \\
\hline 12. & $\begin{array}{l}\text { Mentha arvensis } \\
\text { Hindi: Pudina } \\
\text { (English): [Marsh mint }\end{array}$ & $\mathrm{Ma}$ & $\begin{array}{l}\text { India Eastern } \\
\text { Himalayas, } \\
\text { Euresia, } \\
\text { North and } \\
\text { central } \\
\text { America }\end{array}$ & $\begin{array}{l}\text { Rosmarinic acid, } \\
\text { Limonene, Luteolin, } \\
\text { Caryophyllene, } \\
\text { Neomenthol, } \\
\text { Phellandrene, } \\
\text { Hesperidin, }\end{array}$ & $\begin{array}{l}\text { Anticancer, } \\
\text { Antimicrobial, } \\
\text { Insecticide } \\
\text { Antifungal, } \\
\text { Analgesic, } \\
\text { Carminative, }\end{array}$ & $\begin{array}{l}\text { Digestive } \\
\text { disorders anti } \\
\text { helminthic, } \\
\text { cardio tonic } \\
\text { pain reliever } \\
\text { jaundice } \\
\text { diabetes, }\end{array}$ \\
\hline 13. & Morinda citrifolia & $\mathrm{Mc}$ & India, & Damnacanthal, & $\begin{array}{c}\text { Anticancer, } \\
\text { Antitumor }\end{array}$ & $\begin{array}{l}\text { diabetes, } \\
\text { arthritis, pain, }\end{array}$ \\
\hline
\end{tabular}




\begin{tabular}{|c|c|c|c|c|c|c|}
\hline & $\begin{array}{l}\text { Hindi: } \\
\text { Indian Mulberry, English: } \\
\text { canary-wood }\end{array}$ & & $\begin{array}{l}\text { Southeast } \\
\text { Asia, } \\
\text { Australia, } \\
\text { Polynesia, }\end{array}$ & $\begin{array}{l}\text { Citrifolinoside, } \\
\text { Scopoletin, } \\
\text { Rubiadin, } \\
\text { Morindone, }\end{array}$ & $\begin{array}{l}\text { Antibacterial, } \\
\text { Anthelminthic, } \\
\text { Antituberculosis, } \\
\text { Hypotensive, } \\
\text { Immunostimulatory, }\end{array}$ & $\begin{array}{l}\text { eye problems, } \\
\text { hypertension, } \\
\text { digestive } \\
\text { problems, } \\
\text { AIDS, } \\
\text { depression, }\end{array}$ \\
\hline 14. & $\begin{array}{l}\text { Nigella sativa } \\
\text { English: Black cumin } \\
\text { Hindi: Kalonji }\end{array}$ & Ns & $\begin{array}{l}\text { India, } \\
\text { Pakistan, } \\
\text { Middle east } \\
\text { and South } \\
\text { East Asia }\end{array}$ & $\begin{array}{c}\text { Thymoquinone, } \\
\text { Cymene, } \\
\text { Carvacrol, } \\
\text { Carvone, } \\
\text { Nigellone Nigellicine, } \\
\text { Nigellidine, } \\
\text { Hederin, }\end{array}$ & $\begin{array}{c}\text { Anticancer } \\
\text { Immuno booster } \\
\text { Anti-inflammatory } \\
\text { Antioxidant } \\
\text { Analgesic, } \\
\text { Anti-bacterial, } \\
\text { Bronchodilator, } \\
\text { Cardioprotective, }\end{array}$ & $\begin{array}{c}\text { Diuretic, } \\
\text { Diaphoretic, } \\
\text { liver disorders, } \\
\text { anti-obesity } \\
\text { agent. leprosy, } \\
\text { leukoderma, }\end{array}$ \\
\hline 15. & $\begin{array}{l}\text { Piper longum } \\
\text { Hindi: Pippali English: } \\
\text { Balinese pepper }\end{array}$ & $\mathrm{Pi}$ & $\begin{array}{l}\text { North-East } \\
\text { India, } \\
\text { Southern Sri } \\
\text { Lanka }\end{array}$ & $\begin{array}{l}\text { Piperine, Piperidine, } \\
\text { Methyl piperine, } \\
\text { pipenonaline, } \\
\text { piperettine, }\end{array}$ & $\begin{array}{c}\text { Anticancer, } \\
\text { Antioxidant Anti- } \\
\text { inflammatory, } \\
\text { Hepatoprotective, } \\
\text { Immunomodulatory, } \\
\text { Analgesic } \\
\text { Cardioprotective }\end{array}$ & $\begin{array}{l}\text { Abdominal } \\
\text { tumors and } \\
\text { distention, } \\
\text { respiratory } \\
\text { disorders, } \\
\text { laryngitis, } \\
\text { epilepsy, gout, } \\
\text { paralysis, }\end{array}$ \\
\hline 16. & $\begin{array}{l}\text { Urtica dioica } \\
\text { Hindi: Bichchhu } \\
\text { English: Stinging nettle }\end{array}$ & Ud & $\begin{array}{l}\text { India, } \\
\text { Found } \\
\text { Across the } \\
\text { globe except } \\
\text { all around } \\
\text { Africa } \\
\text { and } \\
\text { Madagascar }\end{array}$ & $\begin{array}{l}\text { Flavonoids, } \\
\text { Polyphenols, } \\
\text { Caumarins, }\end{array}$ & $\begin{array}{c}\text { Anticancer } \\
\text { Immunostimulatory, } \\
\text { Analgesic } \\
\text { Antioxidant, } \\
\text { Anti-inflammatory, } \\
\text { Neuroprotective }\end{array}$ & $\begin{array}{c}\text { Inhibit cell } \\
\text { proliferation in } \\
\text { Benign } \\
\text { Prostatic } \\
\text { Hyperplasia } \\
\text { allergies, } \\
\text { diabetes, kidney } \\
\text { stones, }\end{array}$ \\
\hline 17. & $\begin{array}{l}\text { Vinca rosea } \\
\text { Hindi: Sadabahar English: } \\
\text { Cape periwinkle }\end{array}$ & $\mathrm{Vr}$ & $\begin{array}{l}\text { India, } \\
\text { West Indies, } \\
\text { Nigeria }\end{array}$ & $\begin{array}{l}\text { Vinblastine, } \\
\text { Vincristine, } \\
\text { Vinorelbine } \\
\text { Vindesine } \\
\text { Catharine, }\end{array}$ & $\begin{array}{l}\text { Anti-cancer } \\
\text { Anti-tumor } \\
\text { Anti-diabetic } \\
\text { Hypoglycemic }\end{array}$ & $\begin{array}{l}\text { High blood } \\
\text { pressure, } \\
\text { diabetes } \\
\text { infections }\end{array}$ \\
\hline 18. & $\begin{array}{l}\text { Withania somnifera } \\
\text { Hindi: } \\
\text { Ashwagandha } \\
\text { English: Indian ginseng }\end{array}$ & Ws & $\begin{array}{c}\text { India } \\
\text { (Western } \\
\text { India, Bengal, } \\
\text { Bombay), } \\
\text { Africa, } \\
\text { Mediterranea } \\
\text { n }\end{array}$ & $\begin{array}{c}\text { Withanolides, } \\
\text { Withaferin A, } \\
\text { Wiithasomniferin-A, }\end{array}$ & $\begin{array}{c}\text { Anticancer, } \\
\text { Antitumor, } \\
\text { Antioxidant, } \\
\text { Neuroprotective, } \\
\text { Antianxiety, } \\
\text { Immunomodulator, } \\
\text { Hepatoprotective }\end{array}$ & $\begin{array}{l}\text { antioxidant, } \\
\text { aphrodisiac, } \\
\text { Liver tonic, } \\
\text { insomnia } \\
\text { memory loss, } \\
\text { rheumatism, } \\
\text { paralysis, } \\
\text { immune system } \\
\text { disorders, } \\
\text { skin disorders }\end{array}$ \\
\hline
\end{tabular}




\begin{tabular}{|c|c|c|c|c|c|c|}
\hline 19. & $\begin{array}{l}\text { Wrightia tinctoria } \\
\text { English: Dyer's Oleander } \\
\text { Hindi: Indrajau }\end{array}$ & $\mathrm{Wt}$ & $\begin{array}{c}\text { Throughout } \\
\text { India }\end{array}$ & $\begin{array}{c}\text { Wrightial, } \\
\text { Cycloartenone, } \\
\text { desmosterol } \\
\text { Cycloeucalenol, } \\
\text { Gallic acid, } \\
\text { Rutin, } \\
\text { Quercetin }\end{array}$ & $\begin{array}{c}\text { Anti-cancer, } \\
\text { Anti-microbial, } \\
\text { Anti-diabetic, } \\
\text { Anti-ulcer, } \\
\text { Anti-fungal, } \\
\text { Antioxidant, } \\
\text { Anti-helminthic, } \\
\text { Anti-inflammatory }\end{array}$ & $\begin{array}{c}\text { GI tract } \\
\text { disorders., anti- } \\
\text { venom (snake } \\
\text { venom). } \\
\text { skin diseases, } \\
\text { inflammation, } \\
\text { mumps, wound } \\
\text { heal }\end{array}$ \\
\hline
\end{tabular}

Table 2- Ethnopharmacological properties of herbal plants showing direct/indirect indication for targeting lung cancer

\subsection{Relevance factors analysis}

Classical literature surge analysis was used to estimate the \% relevance of each of the 10 cancer causing factors via the use of scoring analysis with keyword hits. Highest percentage relevance was obtained for Tubulin inhibition (95\%) followed by ALK( 90\%), EGFR(90\%), HDAC(90\%),FGER(85\%),PI3K(85\%), $\operatorname{Akt}(85 \%), \operatorname{Bcl} 2(80 \%)$, STAT $3(80 \%)$ and $\operatorname{KRAS}(75 \%)$ (Table 3 \& Figure 1).

\begin{tabular}{|c|c|c|c|c|c|}
\hline S.No. & $\begin{array}{c}\text { Bioactivity parameter } \\
\text { (BAP) }\end{array}$ & $\begin{array}{l}\text { Total no. of } \\
\text { Hits }\end{array}$ & $\begin{array}{c}\text { Hits } \\
\text { relevance } \\
(\mathbf{N}=\mathbf{2 0})\end{array}$ & $\begin{array}{c}\% \\
\text { relevance }\end{array}$ & $\begin{array}{l}\text { Weightage } \\
\text { score }\end{array}$ \\
\hline 1 & Tubulin & 9825 & 19 & 95 & 21.00 \\
\hline 2 & Anaplastic lymphoma kinase (Alk) & 2233 & 18 & 90 & 19.89 \\
\hline 3 & Epidermal growth factor receptor (EFGR & 18770 & 18 & 90 & 19.89 \\
\hline 4 & Histone deacetylases (HDAC) & 5678 & 18 & 90 & 19.89 \\
\hline 5 & Fibroblast growth factor receptor (FGFR) & 1580 & 17 & 85 & 18.79 \\
\hline 6 & Phosphoinositide 3-Kinase (PI3K) & 19479 & 17 & 85 & 18.79 \\
\hline 7 & $\begin{array}{c}\text { Serine/threonine-specific protein Kinase } \\
0 \mathrm{~B}(\mathrm{Akt})\end{array}$ & 27087 & 17 & 85 & 18.79 \\
\hline 8 & B-cell lymphoma 2 (Bcl-2) & 18379 & 16 & 80 & 17.684 \\
\hline 9 & $\begin{array}{l}\text { Signal Transducer and activator of } \\
\text { transcription 3(STAT3) }\end{array}$ & 6116 & 16 & 80 & 17.684 \\
\hline 10 & $\begin{array}{c}\text { Kirsten rat sarcoma viral oncogene } \\
\text { homolog (KRAS) }\end{array}$ & 3311 & 15 & 75 & 16.579 \\
\hline
\end{tabular}

Table 3: Classical literature surge of Factors involved in lung cancer, showing relative percentage relevance 


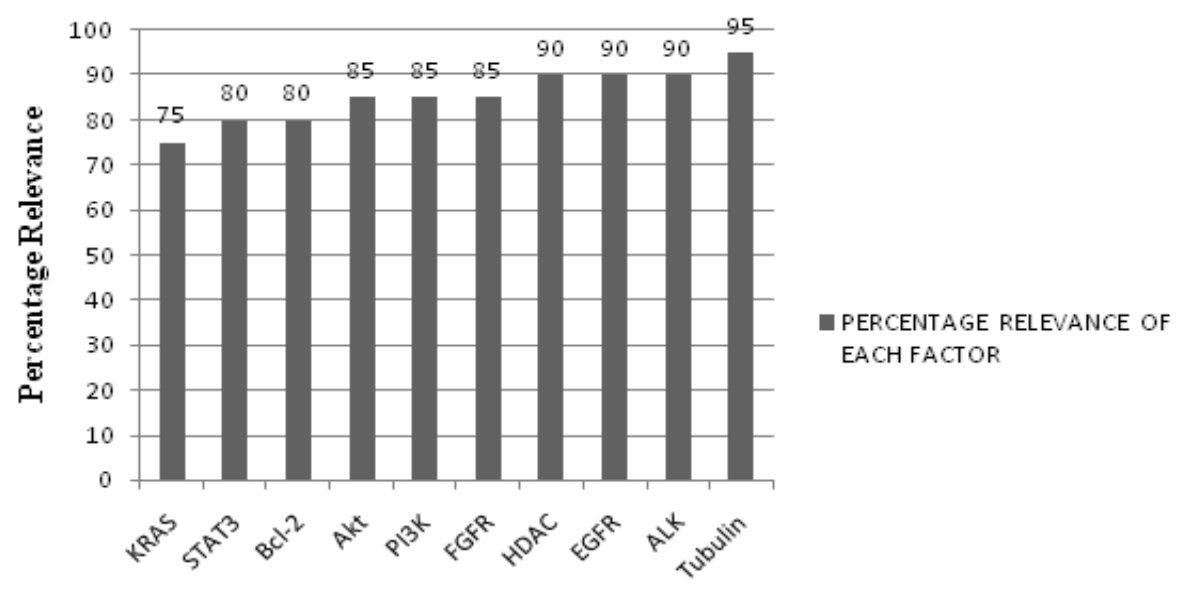

Bio-activity Parameter

Figure 1: Percentage $(\%)$ relevance of Bio-Activity Parameter involved in the pathogenesis of Lung Cancer (KRAS= Kirsten rat sarcoma viral oncogene homolog, STAT3 $=$ Signal Transducer and activator of transcription, Bcl-2 = B-cell lymphoma 2 , Akt= Serine/threonine-specific protein Kinase B, PI3K = Phosphoinositide 3-Kinase, FGFR = Fibroblast growth factor receptor $($ FGFR), HDAC $=$ Histone deacetylases, EGFR $=$ Epidermal growth factor receptor, ALK $=$ Anaplastic lymphoma kinase)

\subsection{Relevance factor linked binary-weightage matrix-based analysis}

The binary matrix analysis of presence/absence of the considered factors in 50 herbals revealed that 20 herbals showed binary score from 10 to 14 . The consequent weightage score matrix analysis of 20 herbals revealed that seven herbals are having more than 10 and these are selected for present study.

\subsection{Decision matrix-based Optimization}

Based on decision matrix analysis, 7 herbals showed highest fuzzy score range from 0.6-1. Amongst these, Withania somnifera (score $=1$ ) held the topmost position with $\mu \mathrm{S}$ score being 1 , relative to the lowest $\mu \mathrm{S}$ score exhibited by Piper longum (score=0.6). Optimized scores were also obtained for the selected herbals based on fuzzy set membership analysis by giving priority to highest score plant. These plants are Withania somnifera (Ws), Berberis vulgaris (Bv), Glycyrrhiza glabra $(G g)$, Andrographis paniculate (Ap), Azadirachta indica (Ai), Cinnamomum verum (Cv), Piper longum $(\mathrm{Pl})$ as mentioned in Figure 2; Table 4.

\begin{tabular}{|l|c|c|c|c|}
\hline S. No & Herbals & Herbal code & Binary Matrix Score & $\begin{array}{c}\text { Fuzzy Score } \\
(\boldsymbol{\mu S})\end{array}$ \\
& & & & \\
\hline $\mathbf{1}$ & Withania somnifera & $\mathrm{Ws}$ & 14 & 1 \\
\hline $\mathbf{2}$ & Berberis vulgaris & $\mathrm{Bvl}$ & 14 & 0.9533 \\
\hline $\mathbf{3}$ & Glycyrrhiza glabra & $\mathrm{Gg}$ & 14 & 0.9467 \\
\hline $\mathbf{4}$ & Andrographis paniculata & $\mathrm{Apn}$ & 14 & 0.9274 \\
\hline $\mathbf{5}$ & Azadirachta indica & $\mathrm{Azi}$ & 13 & 0.8704 \\
\hline $\mathbf{6}$ & Cinnamomum verum & $\mathrm{Cv}$ & 11 & 0.7461 \\
\hline $\mathbf{7}$ & Piper longum & $\mathrm{Pl}$ & 10 & 0.6010 \\
\hline
\end{tabular}

Table 4: Fuzzy set membership analysis for herbal plants screened based on binary and weightage matrix scores. 


\section{Discussion}

The chemotherapy kills the proliferating cancer cells but their long-term uses may cause other serious pathologies like myelotoxicity [20], cardiotoxicity [21], renal toxicity [22], mutation in EGFR gene to the patients [23]. As evident from large number of mortalities because of lung cancer every year or with poor recovery rates the chemotherapy alone is not able to control lung cancer completely. According to the latest lung cancer statistics, the five year survival rate is $19 \%$ which has suggested, there is still a need to find alternative medicines with the holistic approach in treatment. Herbal compounds have various medicinal properties like anti-oxidant, anti-inflammatory, immune booster, antiviral, antibacterial properties etc. as described in Table 2 and number of herbals have shown anti-tumor activities also like Withania somnifera, Cinammomum verum, Nigella sativa, Vinca rosea.

In this present study 'in silico' bioprospection analysis is done, which includes using of PubMed as a random search engine for identification of the potential herbal agents based on rationale selection. Relevant factors (Bio-activity parameters) were selected with respect to their involvement (both direct and indirect) in the pathogenesis of lung cancer. The binary matrix approach is used to identify the herbal agents in this paper on the basis of fuzzy score analysis and these herbals have been shortlisted on the basis of all or none principle, with inclusion of herbal agents only with binary score $\geq 10$ out of 14 . After the first screening step, out of 50 herbals, 20 herbals were screened out for performing weightage matrix and the fuzzy set membership analysis, which finally provided a database of 07 herbals (Figure 2) that showed an acceptable optimized score such as Withania somnifera(Ws), Berberis vulgaris(Bv), Glycyrrhiza glabra(Gg), Andrographis paniculate(Ap), Azadirachta indica(Ai), Cinnamomum verum(Cv), Piper longum( $P l)$.

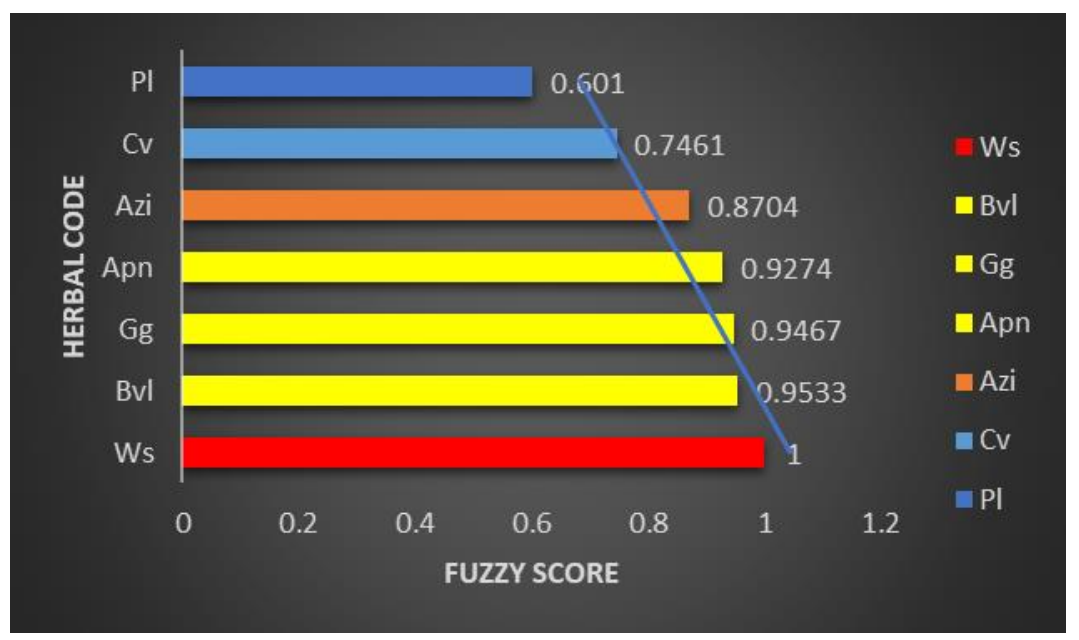

Figure 2: Fuzzy set Optimization of scrutinized Herbals

These scrutinized herbal compounds and their active constituents could also be studied in Molecular Docking and also at 'in vitro' and 'in vivo' model to further assessment of their pharmacological properties in laboratory and their anti- cancer potential can be further tapped in alleviating the disease for drug discovery process.

\section{Conclusion}

Herbal informatic study has provided 07 Herbal compounds i.e., Withania somnifera(Ws), Berberis vulgaris(Bv), Glycyrrhiza glabra(Gg), Andrographis paniculate(Ap), Azadirachta indica(Ai), Cinnamomum verum $(\mathrm{Cv})$, Piper longum $(\mathrm{Pl})$ with significant therapeutic potential targeting several disease factor of lung 
cancers. This study needs to be cross validated at docking level and at in vitro and in vivo level to further establish their role in management of cancer

Acknowledgements: Academic support given by Shivaji college, University of Delhi (DU), India under DBT Star Scheme

\section{Source of Funding: None}

\section{Conflict of interest}

All the authors have contributed towards the conception, designing, and editing of the manuscript. The authors declare no competing financial interests and thereby declare no conflict of interest.

\section{References}

1. Omenn GS, Merchant J, Boatman E, Dement JM, Kuschner M, Nicholson W, et al. Contribution of environmental fibers to respiratory cancer. Environmental health perspectives 1986;70: 51-6.DOI: https://doi.org/10.1289/ehp.867051

2. Matakidou A, Eisen T, Houlston RS. Systematic review of the relationship between family history and lung cancer risk. British journal of cancer 2005;93(7):825-33. DOI: https://doi.org/10.1038/sj.bjc.6602769

3. Bray F, Ferlay J, Soerjomataram I, Siegel RL, Torre LA, Jemal A. Global cancer statistics 2018: GLOBOCAN estimates of incidence and mortality worldwide for 36 cancers in 185 countries. CA: a cancer journal for clinicians 2018;68(6):394-424. DOI: https://doi.org/10.3322/caac.21492

4. Cruz CS, Tanoue LT, Matthay RA. Lung cancer: epidemiology, etiology, and prevention. Clinics in chest medicine 2011;32(4):605-44. DOI: 10.1016/j.ccm.2011.09.001

5. Toyooka S, Mitsudomi T, Soh J, Aokage K, Yamane M, Oto T, et al. Molecular oncology of lung cancer. General thoracic and cardiovascular surgery 2011;59(8):527. DOI: https://doi.org/10.1007/s11748-010-0743-3

6. Ferrara N, Hillan KJ, Gerber HP, Novotny W. Discovery and development of bevacizumab, an antiVEGF antibody for treating cancer. Nature reviews Drug discovery 2004;3(5):391-400. DOI:https://doi.org/10.1038/nrd1381

7. Arbour KC, Riely GJ. Diagnosis and Treatment of Anaplastic Lymphoma Kinase-Positive Non-Small Cell Lung Cancer. Hematology/Oncology Clinics 2017;31(1):101-11 DOI: 10.1016/j.hoc.2016.08.012

8. Soda M, Choi YL, Enomoto M, Takada S, Yamashita Y, Ishikawa S, et al. Identification of the transforming EML4-ALK fusion gene in non-small-cell lung cancer. Nature 2007;448(7153):561-6 .DOI: https://doi.org/10.1038/nature05945

9. Shaw AT, Yeap BY, Mino-Kenudson M, Digumarthy SR, Costa DB, Heist RS, et al. Clinical features and outcome of patients with non-small-cell lung cancer who harbor EML4-ALK. Journal of clinical oncology 2009;27(26):4247 DOI: $\underline{10.1200 / J C O .2009 .22 .6993}$

10. Kim MS, Kwon HJ, Lee YM, Baek JH, Jang JE, Lee SW, et al. Histone deacetylases induce angiogenesis by negative regulation of tumor suppressor genes. Nature medicine 2001;7(4):437-43. DOI: https://doi.org/10.1038/86507 
11. Brognard J, Clark AS, Ni Y, Dennis PA. Akt/protein kinase B is constitutively active in non-small cell lung cancer cells and promotes cellular survival and resistance to chemotherapy and radiation. Cancer research 2001;61(10):3986-97. PMID: 11358816

12. Pérez-Ramírez C, Cañadas-Garre M, Molina MÁ, Faus-Dáder MJ, Calleja-Hernández MÁ. PTEN and $\mathrm{PI} 3 \mathrm{~K} / \mathrm{AKT}$ in non-small-cell lung cancer. Pharmacogenomics 2015;16(16):1843-62.DOI: https://doi.org/10.2217/pgs.15.122

13. Maounis NF, Dráberová E, Mahera H, Chorti M, Caracciolo V, Sulimenko T, et al. Overexpression of $\gamma$-tubulin in non-small cell lung cancer. Histol Histopathol 2012;27:1183-94.DOI: 10.14670/HH$\underline{27.1183}$

14. Ornitz DM, Itoh N. The fibroblast growth factor signaling pathway. Wiley Interdisciplinary Reviews: Developmental Biology 2015;4(3):215-66.DOI:https://doi.org/10.1002/wdev.176

15. Oladipupo SS, Smith C, Santeford A, Park C, Sene A, Wiley LA, et al. Endothelial cell FGF signaling is required for injury response but not for vascular homeostasis. Proceedings of the National Academy of Sciences 2014;111(37):13379-84. DOI: https://doi.org/10.1073/pnas.1324235111

16. Ohgino K, Soejima K, Yasuda H, Hayashi Y, Hamamoto J, Naoki K, et al. Expression of fibroblast growth factor 9 is associated with poor prognosis in patients with resected non-small cell lung cancer. Lung Cancer 2014;83(1):90-6. DOI: https://doi.org/10.1016/j.lungcan.2013.10.016

17. Woll PJ. New perspectives in lung cancer. 2. Growth factors and lung cancer. Thorax 1991;46(12):924. DOI: $10.1136 /$ thx.46.12.924

18. Carcereny E, Morán T, Capdevila L, Cros S, Vilà L, de los Llanos Gil M, et al. The epidermal growth factor receptor $(E G R F)$ in lung cancer. Translational respiratory medicine 2015;3(1):1. DOI: https://doi.org/10.1186/s40247-015-0013-z

19. Hirsch FR, Scagliotti GV, Mulshine JL, Kwon R, Curran Jr WJ, Wu YL, et al. Lung cancer: current therapies and new targeted treatments. The Lancet 2017;389(10066):299-311.DOI: https://doi.org/10.1016/S0140-6736(16)30958-8

20. Macdonald JS. Toxicity of 5-fluorouracil. Oncology (Williston Park, NY) 1999;13(7, Suppl 3):33-4. PMID: 10442356

21. Kilickap S, Akgul E, Aksoy S, Aytemir K, Barista I. Doxorubicin-induced second degree and complete $\begin{array}{lllll}\text { atrioventricular } \quad \text { block. } & \text { EP }\end{array}$ https://doi.org/10.1016/j.eupc.2004.12.012

22. Pinzani V, Bressolle F, Haug IJ, Galtier M, Blayac JP, Balmès P. Cisplatin-induced renal toxicity and toxicity-modulating strategies: a review. Cancer chemotherapy and pharmacology 1994;35(1):1-9. DOI: https://doi.org/10.1007/BF00686277

23. Engelman JA, Jänne PA. Mechanisms of acquired resistance to epidermal growth factor receptor tyrosine kinase inhibitors in non-small cell lung cancer. Clinical Cancer Research 2008;14(10):28959. DOI: $10.1158 / 1078-0432 . C C R-07-2248$

24. Chakotiya AS, Chawla R, Thakur P, Tanwar A, Narula A, Grover SS, et al. In vitro bactericidal activity of promising nutraceuticals for targeting multidrug resistant Pseudomonas aeruginosa. Nutrition 2016;32(7-8):890-7.DOI:https://doi.org/10.1016/j.nut.2016.01.024

25. Desai AG, Qazi GN, Ganju RK, El-Tamer M, Singh J, Saxena AK, et al. Medicinal plants and cancer chemoprevention. Current drug metabolism 2008;9(7):581-91. DOI: https://doi.org/10.2174/138920008785821657 
26. Amin A, Gali-Muhtasib H, Ocker M, Schneider-Stock R. Overview of major classes of plant-derived anticancer drugs. International journal of biomedical science: IJBS 2009;5(1):1.PMID: 23675107

27. Subapriya R, Nagini S. Medicinal properties of neem leaves: a review. Current Medicinal ChemistryAnti-Cancer Agents 2005;5(2):149-56. DOI: https://doi.org/10.2174/1568011053174828

28. Wang L, Do Dang Khoa Phan JZ, Ong PS, Thuya WL, Soo R, Wong AL, et al. Anticancer properties of nimbolide and pharmacokinetic considerations to accelerate its development. Oncotarget 2016;7(28):44790.DOI: $\underline{10.18632 / \text { oncotarget.8316 }}$

29. Tanwar A, Thakur P, Chawla R, Ansari MM, Chakotiya AS, Gusain S, et al. Curative remedies for rheumatoid arthritis: herbal informatics approach for rational based selection of natural plant products. Indian Journal of Traditional Knowledge 2017;16(1):128-33 DOI: http://nopr.niscair.res.in/handle/123456789/37025

30. World Health Organization, "Cancer", Available at: https://www.who.int/news-room/factsheets/detail/cancer (August 2018), Accessed on: 15 October 2020

31. Tanwar A, Zaidi AA, Kaur H, Rana N, Chawla R, Basu M, et al. In silico bioprospection analysis for identification of herbal compound targeting Clostridium difficile. Indian Journal of Traditional Knowledge (IJTK) 2019;18(4):655-61.

DOI: http://op.niscair.res.in/index.php/IJTK/article/view/28947

32. Cancer.Net, "Lung Cancer-Non-Small Cell: Statistics", Available at:https://www.cancer.net/cancertypes/lung-cancer-non-small-cell/statistics (May 2020), Accessed: 15 October 2020.

33. Tanwar A, Zaidi AA, Bhardwaj M, Rathore A, Chakotiya AS, Sharma N, et al. Herbal informatics approach for the selection of natural compounds targeting diabetes mellitus. Indian Journal of Traditional 